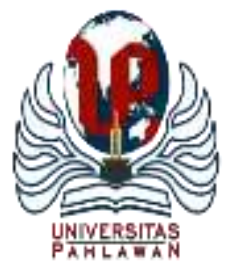

Edukatif : Jurnal Ilmu Pendidikan Volume 4 Nomor 1 Tahun 2022 Halm 925 - 933

EDUKATIF: JURNAL ILMU PENDIDIKAN

Research \& Learning in Education

https://edukatif.org/index.php/edukatif/index

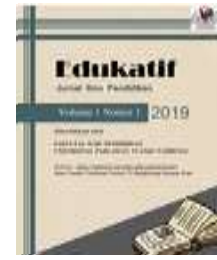

\title{
Pengaruh Kepemimpnan Kepala Sekolah, Struktur Organisasi, Motivasi Kerja Guru Terhadap Kinerja Guru
}

\author{
Tri Puspita Sari ${ }^{1 凶}$, Eddy Haryanto $^{2}$, Mohammad Muspawi ${ }^{3}$ \\ Universitas Jambi, Indonesia ${ }^{1,2,3}$ \\ E-mail : triipuspitasariii848@gmail.com ${ }^{1}, \underline{\text { eharyanto@yahoo.com }}^{2}, \underline{\text { muspawi01@gmail.com }}^{3}$
}

\begin{abstract}
Abstrak
Latar belakang penelitian rendahnya kinerja guru belum membuat rancangan pelaksanaan pembelajaran dan mengembangkan, menerapkan program penilaian terhadap peserta didik. Tujuan penelitian untuk mengetahui gambaran tentang kepemimpinan kepala sekolah, struktur organisasi, motivasi kerja guru terhadap kinerja guru. Metode penelitian pendekatan kuantitatif dengan metode korelasi. Hasil penelitian menunjukkan terdapat pengaruh langsung kepemimpinan kepala sekolah terhadap kinerja guru, terdapat pengaruh langsung struktur organisasi terhadap kinerja guru, terdapat pengaruh signifikan kepemimpinan kepala sekolah terhadap motivasi kerja guru, terdapat pengaruh langsung struktur organisasi terhadap motivasi kerja guru, terdapat pengaruh motivasi kerja terhadap kinerja guru, terdapat pengaruh tidak langsung kepemimpinan terhadap kinerja guru melalui motivasi kerja guru, terdapat pengaruh tidak langsung struktur organisasi terhadap kinerja guru melalui motivasi kerja guru. Kesimpulan bahwa adanya pengaruh langsung dan tidak langsung kepemimpnan kepala sekolah, struktur organisasi, dan motivasi kerja, terhadap kinerja guru.
\end{abstract}

Kata kunci: Kepemimpnan Kepala Sekolah, Struktur Organisasi, Motivasi Kerja, dan Kinerja Guru

Abstract

The research background for the low performance of teachers has not yet made a learning implementation plan and developed, implemented an assessment program for students. The purpose of the study was to determine the description of the principal's leadership, organizational structure, teacher work motivation on teacher performance. The research method is a quantitative approach with the correlation method. The results showed that there was a direct influence of the principal's leadership on teacher performance, there was a direct influence of organizational structure on teacher performance, there was a significant influence of principal's leadership on teacher work motivation, there was a direct influence of organizational structure on teacher work motivation, there was an influence of work motivation on teacher performance, there is an indirect effect of leadership on teacher performance through teacher work motivation, there is an indirect effect of organizational structure on teacher performance through teacher work motivation. The conclusion is that there are direct and indirect effects of principal leadership, organizational structure, and work motivation on teacher performance.

Keywords: Principal Leadership, Organizational Structure, Work Motivation, and Teacher Performance

Copyright (c) 2022 Tri Puspita Sari, Eddy Haryanto, Mohammad Muspawi

$\triangle$ Corresponding author:

Email : triipuspitasariii848@gmail.com

DOI : https://doi.org/10.31004/edukatif.v4i1.2040

ISSN 2656-8063 (Media Cetak)

ISSN 2656-8071 (Media Online)

Edukatif : Jurnal Ilmu Pendidikan Vol 4 No 1 Tahun 2022

p-ISSN 2656-8063 e-ISSN 2656-8071 


\section{PENDAHULUAN}

Pendidikan merupakan wahana yang sangat strategis dalam meningkatkan kualitas sumber daya manusia yang merupakan faktor determinan pembangunan. Pendidikan adalah usaha sadar untuk menyiapkan peserta didik melalui kegiatan bimbingan, pengajaran, dan atau latihan bagi peranannya di masa yang akan dating UU SPN No. 20 Tahun 2003 (Sah, K., \& Mulyasa, E., 2018). Dengan tidak bermaksud mengecilkan kontribusi komponen yang lainnya, komponen tenaga kependidikan atau guru merupakan salah satu faktor yang sangat esensi dalam menentukan kualitas peserta didiknya.

Menurut Barnawi dan Arifin (Deikme, P, 2013) "Guru sebagai seorang professional mempertaruhkan profesi pada kualitas kerjanya". Hal ini menegaskan bahwa kinerja yang berkualitas akan menggambarkan kualitas professional seorang guru, dan sebaliknya kinerja yang dibawah standar kerja menggambarkan ketidakberhasilan guru menghormati profesinya sendiri. Oleh karena itu, pembinaan dan pengembangan profesi guru dipandang perlu diperhatikan sebagai wujud komitmen dalam melakukan pembenahan pola pendidikan agar mencapai mutu pendidikan sesuai harapan. Kualitas kemampuan guru yang rendah akan berdampak pada rendahnya mutu pendidikan. Kinerja guru adalah perilaku nyata sebagai suatu prestasi kerja yang ditampilkan oleh seorang tenaga pengajar untuk melaksanakan proses pendidikan di sekolah atau lembaga pendidikan.

Kinerja guru adalah hasil kerja yang dapat dicapai oleh seorang guru di lembaga pendidikan atau madrasah sesuai dengan tugas dan tanggung jawab dalam mencapai tujuan pendidikan Asf \& Mustofa (Antou, 2013) Keberhasilan seorang guru harus memenuhi kriteria yang telah ditetapkan, apabila guru telah memenuhi kriteria tersebut berarti seorang guru dapat dikatakan berhasil dan memiliki kualitas yang baik. Sebaliknya apabila seorang guru belum memenuhi kriteria yang baik maka guru belum dapat dikatakan berhasil. Keberhasilan kinerja guru dalam pekerjaannya karena ia memiliki kemampuan dan ketrampilan untuk itu, dan hubungan interaktif berbagai aspek dalam bekerja. seperti alat-alat, metode atau cara kerja, hubungan dengan rekan sekerja, dan lain-lain.

Kinerja di hasilkan oleh kemampuan dan disiplin yang dimiliki oleh seseorang. Jika seseorang memiliki kemampuan yang tinggi namun tidak memiliki disiplin yang baik maka tidak akan menghasilkan kinerja yang baik, begitu pula sebaliknya. Kemampuan mengajar merupakan hal yang sangat penting. Karena semakin baik kemampuan mengajar guru makan akan semakin tinggi prestasi yang dicapai. Tanpa adanya kemampuan mengajar guru maka akan semakin tinggi prestasi yang dicapai. Tanpa adanya kemampuan mengajar guru baik yang sulit bagi pendidikan untuk mencapai hasil yang maksimal.

Dalam hal ini kemampuan yang dimaksud adalah kompetensi yang dimiliki oleh guru tersebut. Sebagaimana dijelaskan oleh Marsana dan Handayani (Mastura, D., GIMIN, G., \& BURHANUDDIN, D, 2017) bahwa Penentuan tingkat kompetensi dibutuhkan agar dapat mengetahui tingkat kinerja yang baik diharapkan untuk kategori yang baik atau rata-rata. Penentuan ambang kompetensi yang dibutuhkan tentunya akan dapat dijadikan dasar bagi proses seleksi, sukses perencanaan, evaluasi kinerja, dan pengembangan SDM.

Menurut undang-undang republik indonesia Nomor 14 tahun 2005 tentang Guru dan Dosen, kompetensi adalah seperangkat pengetahuan, keterampilan dan perilaku yang harus dimiliki, dihayati dan dikuasai oleh guru atau dosen yang melaksanakan tugas keprofesionalannya. Guru mempunyai peranan penting dalam proses pembelajaran, sehingga seorang guru harus memiliki kompetensi profesional yang tinggi dan menghasilkan manusia yang memiliki SDM yang tinggi. Guru yang profesional adalah guru yang memiliki empat kompetensi yaitu, kompetensi pedagogik, kompetensi kepribadian, kompetensi profesional, dan kompetensi sosial. Selain itu, kedisiplinan juga sangat berpengaruh terhadap kinerja seorang guru, tanpa ada kedisiplinan seorang guru tidak akan bisa bekerja sesuai dengan apa yang diharapkan. Pada umumnya seorang guru dapat mencapai harapan dalam bekerja apabila terdapat disiplin diri yang baik. Disiplin yang baik 
mencerminkan besarnya rasa tanggung jawab seseorang terhadap tugas-tugas yang diberikan kepadanya. Hal ini mendorong gairah kerja, semangat kerja, dan terwujudnya tujuan sekolah, guru, dan masyarakat. Oleh karena itu, setiap pimpinan baik di sekolah maupun perusahaan selalu berusaha agar para guru mempunyai disiplin yang baik demi keberhasilan dalam mencetak para siswanya.

Permasalahan-permasalahan mengenai kinerja guru yang ada saat ini dapat terjadi pada semua daerah di Indonesia termasuk salah satunya adalah di Kabupaten Tebo. Berdasarkan hasil survei lapangan yang penulis peroleh dari salah seorang guru. Kinerja guru yang ada di Seluruh SMA Negeri yang ada di kabupaten tebo masih ditemukan guru yang belum menjalankan tugas seperti merencanakan, melaksanakan, dan mengevaluasi pembelajaran dengan baik. Permasalahan yang terjadi antara lain seperti guru yang belum membuat rancangan pelaksanaan pembelajaran dalam merencanakan pembelajaran maupun guru yang belum mengembangkan serta menerapkan program penilaian terhadap peserta didik. Berdasarkan uraian diatas, peneliti menyadari bahwa kualitas guru sangat berpengaruh terhadap terbentuknya peserta didik yang berkualitas pula. Guru memiliki peran penting dalam kemajuan mutu pendidikan.

Penelitian yang relevan dengan penelitian ini pertama, dilakukan oleh Basilius Redan Werang,Universitas Musamus Merauke Papua, telah melakukan penelitian yang berjudul Pengaruh Kepemimpinan Transformasi Kepala Sekolah, Moral Kerja Guru, dan Kepuasan Kerja Terhadap Kinerja Guru SDN di Kota Merauke. Kedua, dilakukan oleh Mutmainah, Universitas Negeri Yogyakarta, penelitian ini berjudul Pengaruh Kepemimpinan Kepala Sekolah dan Profesional Guru Terhadap Kinerja Guru SMK Negeri 1 Tepus. Ketiga, penelitian yang dilakukan Sahrul, Universitas IslamNegeriAlaudin Makasar, Penelitian Ini Berjudul. Pengaruh Struktur Organisasi Terhadap Kinerja Karyawan Pada Kantor Pelayanan Pajak (KPP) Pratama Makassar Utara. Keempat, penelitian yang dilakuakan Titin Eka Ardiana, Universitas Muhamdya Ponorogo, Penelitian Ini Berjudul. Pengaruh ,otivasi Kerja Guru Terhadap Kinerja Guru Akuntansi di kota madiun. Penelitian ini bertujuan untuk mengetahui pengaruh motivasi kerja terhadap kinerja guru akuntansi. Kelima, Tatiek Nurhayati Dkk, Universitas Islam Agung. Penelitian Ini berjudul peran struktur organisasi dan system remunerasi dalam kinerja.

Tujuan penelitian dilakukan untuk melihat gambaran pengaruh secara langsung dan tidak langsung kepemimpnan kepala sekolah, struktur organisasi, dan motivasi kerja terhadap kinerja guru.

\section{METODE PENELITIAN}

Adapun kerangka berpikir dari penelitian ini adalah sebagai berikut :

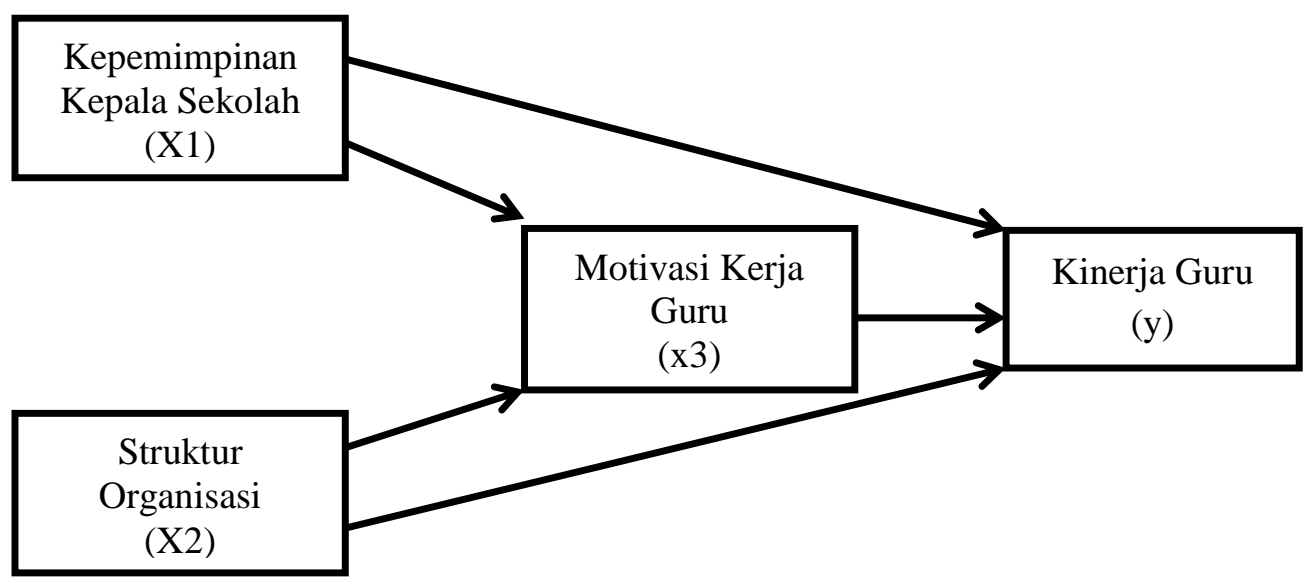

Gambar 1. Paradigma Penelitian

Hipotesis yang diajukan dalam penelitian ini adalah :

1. $H_{a 1}$ : Terdapat pengaruh langsung kepemimpinan kepala sekolah terhadap kinerja guru SMA Negeri di kabupaten Tebo 
928 Pengaruh Kepemimpnan Kepala Sekolah, Struktur Organisasi, Motivasi Kerja Guru Terhadap Kinerja Guru - Tri Puspita Sari, Eddy Haryanto, Mohammad Muspawi

DOI: https://doi.org/10.31004/edukatif.v4i1.2040

2. $H_{a 2}$ : Terdapat pengaruh langsung Struktur Organisasi terhadap kinerja Guru pada SMA Negeri di Kabupaten kabupaten Tebo

3. $H_{a 3}$ : Terdapat pengaruh langsung kepemimpinan kepala sekolah terhadap Motivasi kerja guru SMA Negeri di kabupaten Tebo

4. $H_{a 4}$ : Terdapat pengaruh langsung Struktur Organisasi terhadap Motivasi kerja Guru SMA Negeri di Kabupaten kabupaten Tebo

5. $H_{a 5}$ : Terdapat pengaruh langsung motivasi kerja guru terhadap kinerja guru SMA Negeri di kabupaten Tebo

6. $H_{a 6}$ :Terdapat pengaruh tidak lansung kepemimpinan kepala sekolah terhadap kinerja guru melalui motivasi kerja guru SMA Negeri di kabupaten Tebo

7. $H_{a 7}$ : Terdapat pengaruh tidak langsung struktur organisasi terhadap kinerja guru melalui motivasi kerja guru SMA Negeri di kabupaten Tebo.

Penelitian ini menggunakakan pendekatan kuantitatif. Penelitian kuantitatif merupakan metode-metode untuk menguji teori-teori tertentu dengan cara meneliti hubungan antar variabel. Variabel-variabel ini diukur sehingga data yang terdiri dari angka-angka dapat dianalisis berdasarkan prosedur-prosedur statistik (Creswell John. W, 2012) pada dasarnya, pendekatan kuantitatif dilakukan pada penelitian inferensial (dalam rangka pengujian hipotesis) dan menyadarkan kesimpulan hasilnya pada suatu probabilitas kesalahan penolakan hipotesis nihil. Metode yang digunakan dalam penelitian ini adalah korelasi dengan tujuan untuk mendeteksi sejauh mana variasi-variasi pada suatu factor berkaitan dengan variasi-variasi pada satu atau lebih factor lain berdasarkan pada koefisien korelasi. Dimana penelitian korelasi menurut Arikunto, adalah penelitian yang dimaksud untuk mengetahui ada dan tidaknya hubungan atau pengaruh antara dua variabel atau lebih (Arikunto, Prosedur Penelitian, 2013).

Penelitian ini dilakukan di Seluruh SMA Negeri Sekabupaten Tebo, dengan melakukan penelitian penyebaran instrument (Angket) pada seluruh Sekolah SMA Negeri yang ada di Kabupaten tebo dengan jumlah Sekolah Yaitu 19 Sekolah. Menurut Wahid (FR, G. G., \& Nurohmi, A. F, 2017) , data merupakan keterangan atau bahan nyata yang dapat dijadikan dasar kajian (analisis/kesimpulan). Data yang dikumpulkan dapat berupa data primer, yakni data yang diperoleh secara langsung dari sumbernya. Sedangkan data sekunder merupakan data yang diperoleh dari informasi yang telah diolah oleh pihak lain, seperti segala macam bentuk dokumen. Data primer ini diperoleh melalui hasil angket kepemimpinan kepala sekolah, Struktur Organisasi, motivasi Kera Guru dan kinerja Guru.

Adapun populasi dalam penelitian adalah Seluruh guru SMA Negeri Sekabupaten Tebo dengan jumlah guru sebanyak 491 guru. Dalam penelitian ini, populasinya berjumlah 491 Guru, maka penelitian ini merupakan penelitian sampel. Dengan berbagai pertimbangan, penelitian ini mengambil sampel $15 \%$ dari keseluruhan populasi yang berjumlah 491 maka sampel yang digunakan berjumlah 74 subyek. Teknik pengambilan sampel pada penelitian ini dengan menggunakan random sampling atau sampel acak.

Instrumen yang digunakan pada penelitian ini berupa pernyataan untuk angket. Untuk mengukur instrumen penelitian ini peneliti menggunakan Skala Likert. Skala likert merupakan skala yang digunakan untuk mengukur sikap, pendapat, serta persepsi seseorang atau sekelompok tentang kejadian atau gejala sosial (Sudaryono, dkk 2012:49). Model skala likert yang digunakan adalah empat kriteria yaitu sangat setuju, setuju, kurang setuju, dan tidak setuju. Penelitian ini dilakukan dengan teknik sampling atau probability sampling yaitu teknik pengambilan sampel yang memberikan suatu peluang yang sama untuk semua unsur populasi yang dipilih menjadi anggota sampel. Teknik ini meliputi random sampling atau sampel secara acak, merupakan pengambilan sampling secara random atau tanpa pandang bulu.Teknik Pengumpulan Data mengunakan angket dan dokumentasi.

Teknis analisis data digunakan untuk mengetahui bagaimana pengaruh kepemimpinan kepala sekolah, struktur organisasi dan motivasi kerja terhadap kinerja guru SMA Negeri di Kabupaten Tebo. Teknik Analisa data pada penelitian ini menggunakan teknik personally administered questionnaires, yaitu kuesioner 
disampaikan dan dikumpulkan langsung oleh peneliti Indriantoro dan Supomo (Iskandar, 2013) analisis data digunakan untuk menjawab pertanyaan penelitian, menguraikan keseluruhan menjadi komponen yang lebih kecil guna mengetahui komponen mana yang dominan, membandingkan antar komponen serta membandingkan salah satu atau beberapa komponen dengan keseluruhan komponen.

Analisis yang digunakan pada penelitian ini adalah teknik analisis deskriptif, yaitu suatu teknik analisis yang digunakan untuk mengambarkan variable Kepemimpinan, struktur organisasi, motivasi,dan kinerja guru dengan cara menyusun tabel distribusi frekwensi untuk melihat dan memasukan dalam kategori manakah variabel yang akan diteliti. Pengelolaan data penelitian ini menggunakan Software Smart PLS 3.2.7. Structural Equation Modelling (SEM) merupakan suatu metode yang dipakai untuk menutup kelemahan yang terdapat pada metode regresi. Menurut para ahli metode penelitian SEM dikelompokan menjadi dua, yaitu pendekatan Covariance Based SEM (CBSEM) dan Variance Based SEM atau Partial Least Square (PLS) (Ghozali, I., \& Purwanto).

\section{HASIL DAN PEMBAHASAN PENELITIAN}

Untuk melihat kinerja dari masing masing variable penulis mengunakan teknik IPMA analisis. Analisis matriks kinerja-kepentingan (IPMA) memberikan teknik tambahan bagi peneliti untuk memperkaya Analisis PLS-SEM, dan dengan demikian memperoleh hasil tambahan Ringle \& Sarstedt (Sah \& Mulyasa, E, 2018). IPMA mengambil kinerja dari setiap konstruksi memperhitungkan dan membedakan efek total model struktural (dimensi kepentingan). Juga, kinerja rata-rata dari setiap variabel laten menyoroti faktor penentu penting untuk peningkatan praktik manajemen (Hair, J. F., , Risher, J. J., , Sarstedt, M.,, \& Ringle, 2019). Ringle dan Sarstedt (Sah \& Mulyasa, E, 2018) mengemukakan bahwa IPMA memprioritaskan konstruksi untuk meningkatkan konstruksi target tertentu. IPMA memperoleh efek total dari hubungan konstruksi lainnya (yaitu, Variabel kepemimpinan, Struktur Organisasi Motivasi dan Kinerja guru, dibawah ini dapat dilihat kenerja dari masing masing varibel mana yang paling baik dan perlu ditingkatkan kinerja variablenya.

Tabel 1

Pemetaan Masing Masing Variable

\begin{tabular}{lr}
\hline Variabel & Kinerja LV \\
\hline Kepemimpinan Kepala Sekolah & 61,553 \\
\hline Kinerja & 87,518 \\
\hline Motivasi Kerja & 54,509 \\
\hline Struktur Organisasi & 51,086 \\
\hline
\end{tabular}

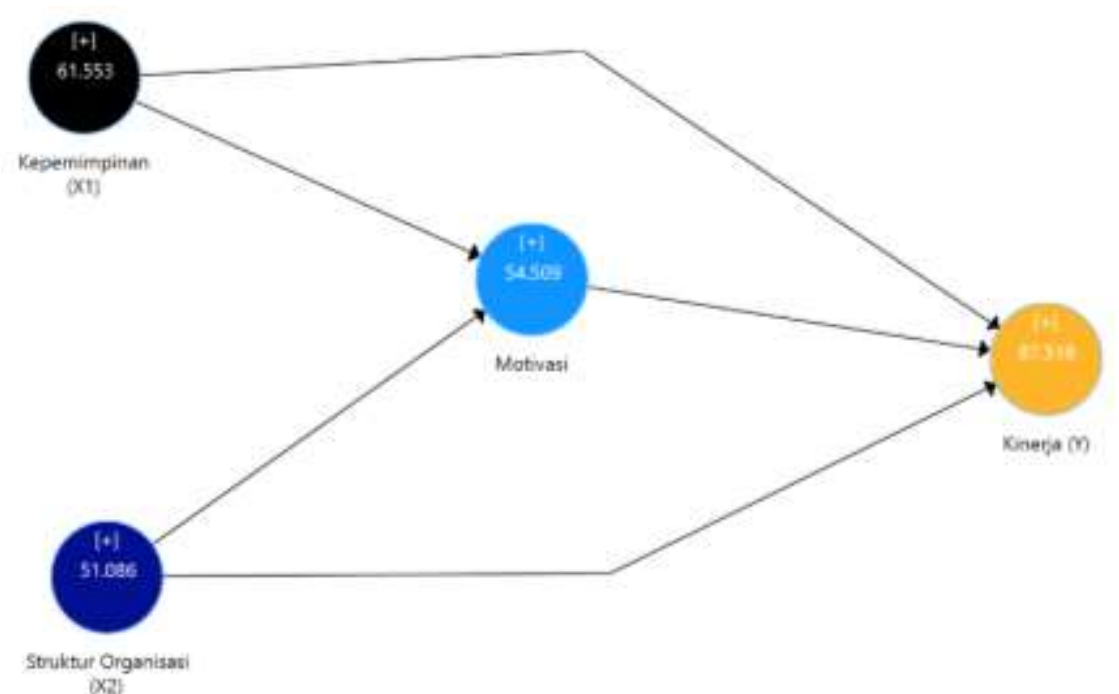

Gambar 2. Pemetaan Masing Masing Variable

Edukatif : Jurnal Ilmu Pendidikan Vol 4 No 1 Tahun 2022 p-ISSN 2656-8063 e-ISSN 2656-8071 
Gambar 1. Pemetaan Masing Masing Variable di atas dapat dijelaskan bahwa Pemetaan dari masih dapat dilihat dari angka yang tertera di dalam kolom tersebut di mana dapat dilihat kinerja dari variabel Motivasi dan struktur organisasi masih rendah dibandingkan variabel yang lain artinya dalam kondisi ini pemimpin perlu melakukan evaluasi dan juga menbuat guru merasa nyaman sehingga motivasi guru menjadi meningkat selain itu guru belum merasa begitu termotivasi dengan kondisi yang ada perlu adanya perbaikan selanjutnya struktur organisasi yang baik dirasa mampu meningkatkan motivasi selajuntya dibandingkan dengan variabel yang lain di mana kinerja dari guru merupakan indikator kinerja variabel yang paling tinggi dibandingkan variabel yang lain yaitu sebesar $87 \%$ dan variabel kepemimpinan juga kinerja variabel ini sebesar $61 \%$ jadi kinerja variabel yang tertinggi yaitu pada variabel kinerja Guru artinya Guru sudah merasa puas dan kepemimpinan yang ada mampu memberikan mereka motivasi dan tentunnya dengan pengunaan IPMA dapat memberikan kita informasi untuk memetakan mana yang variabel yang perlu ditingkatkan.

Hipotesis pertama menguji apakah Pengaruh kepemimpinan terhadap Kinerja secara P Values positif berpengaruh terhadap Kinerja Guru. Hasil pengujian menunjukkan bahwa ada pengaruh yang signifikan. Dimana nilai $\mathrm{p}$ Value dibawah 0,05 hipotesis pertama diterima. Hal tersebut membuktikan bahwa Kepemimpinan Kepala sekoah meiliki pengaruh dengan Original Sample sebesar 0,514 (51,4\%).

Berdasakan Penelitian Terdahulu yang berjudul Hubungan kepemimpinan Kepala sekolah dan sikap Guru Terhadap Pekerjaan dengan Kompetensi Profesional Guru SMA Negeri di Kabupaten Pandeglang Sopiah Merekomendasikan Bahwa terdapat hubungan Positif dan signifikan antara Kepemimpinan Kepala sekolah dengan kompetensi profesional Guru.

Hipotesis kedua menguji apakah Terdapat Pengruh Struktur Organisasi terhadap Kinerja Guru secara P Values positif artnya terdapat pengaruh Struktur organisasi terhadap Kinerja . Hasil pengujian menunjukkan bahwa ada pengaruh yang signifikan. Dimana nilai $\mathrm{p}$ Value dibawah 0,05 hipotesis Kedua diterima. Hal tersebut membuktikan Struktur Organisasi berpengruh terhadap Kinerja dengan Original Sample sebesar $0,219(21,9 \%)$.

Penelitian ini sejalan dengan penelitian Sahrul, Universitas Islam Negeri Alaudin Makasar, Penelitian Ini Berjudul. Pengaruh Struktur Organisasi Terhadap Kinerja Karyawan Pada Kantor Pelayanan Pajak (KPP) Pratama Makassar Utara. Pokok permasalahan yang di bahas dalam skripsi ini yaitu bagaimana pengaruh struktur organisasi terhadap kinerja karyawan pada kantor pelayanan pajak pratama makassar utara. Tujuan pembahasan ini untuk mengetahui sejauh mana pengaruh satruktur oganisasi terhadap kinerja pada karyawan pada kantor Pelayanan Pajak Pratama Makassar utara. Sebagaimana teori mengatakan bahwa adanya pengaruh dari struktur organisasi terhadap kinerja karyawan di suatu perusahaan, tergantung pada bentuk struktur organisasi yang di gunakan. Penelitian ini dilakukan untuk mengetahui pengaruh struktur organisasi terhadap kinerja karyawan baik secara simultan maupun parsial pada Kantor Pelayanan Pajak (KPP) Pratama Makassar Utara.

Hipotesis ketiga menguji apakah Terdapat pengaruh langsung Kepemimpinan Kepala sekolah terhadap Motivasi Kerja Guru pada SMA Negeri di Kabupaten tebo secara P Values positif artinya Terdapat pengaruh langsung Kepemimpian terhadap Motivasi. Hasil pengujian menunjukkan bahwa ada pengaruh yang signifikan. Dimana nilai p Value dibawah 0,05 hipotesis Keempat diterima. Hal tersebut membuktikan pengaruh dengan Original Sample sebesar 0,341 (34,1\%).

Penelitian ini sejalan dengan penelitian Titin Eka Ardiana, Universitas Muhamdya Ponorogo, Penelitian Ini Berjudul. Pengaruh ,otivasi Kerja Guru Terhadap Kinerja Guru Akuntansi di kota madiun. Penelitian ini bertujuan untuk mengetahui pengaruh motivasi kerja terhadap kinerja guru akuntansi. Penelitian ini menggunakan pendekatan studi korelasional dengan sampel yang diambil dari guru akuntansi di SMK kota Madiun secara cluster random sampling sebanyak 97 orang. Variabel penelitian ini terdiri atas satu variabel bebas yaitu: motivasi kerja (X) dan satu variabel terikat yaitu: kinerja guru akuntansi (Y). Pengumpulan data dilakukan dengan menggunakan alat kuesioner berstruktur tertutup. Hasil pengumpulan data selanjutnya 
931 Pengaruh Kepemimpnan Kepala Sekolah, Struktur Organisasi, Motivasi Kerja Guru Terhadap Kinerja Guru - Tri Puspita Sari, Eddy Haryanto, Mohammad Muspawi

DOI: https://doi.org/10.31004/edukatif.v4i1.2040

dianalisis menggunakan teknik analisis regresi sederhana dan regresi berganda dengan bantuan SPSS Versi 20. Hasil penelitian menunjukkan bahwa motivasi kerja berpengaruh secara positif terhadap kinerja guru akuntansi dengan kontribusi sebesar 80,6\%, selebihnya sebesar 19,4\% kinerja guru akuntansi ditentukan oleh faktor-faktor lain diluar penelitian.

Hipotesis Keempat menguji apakah Terdapat pengaruh langsung Sturktur Organisasi terhadap Motivasi Guru pada SMA Negeri di Kabupaten Tebo secara P Values positif artinya Terdapat pengaruh langsung Struktur Organisasi terhadap Motivasi. Hasil pengujian menunjukkan bahwa ada pengaruh yang signifikan. Dimana nilai $\mathrm{p}$ Value dibawah 0,05 hipotesis Keempat diterima. Hal tersebut membuktikan pengaruh dengan Original Sample sebesar 0,684 (68,9\%).

Penelitian ini sejalan dengan penelitian dari Chen dan Huang, Struktur organisasi juga mencerminkan cara di mana informasi dan pengetahuan didistribusikan dalam suatu organisasi, yang mempengaruhi efisiensi pemanfaatannya sehingga semakin efektif dan meningkatkan gairah dan motivasi karywan. Akibatnya, secara substansial mempengaruhi distribusi dan koordinasi sumber daya perusahaan, proses komunikasi dan interaksi sosial antara anggota organisasi.

Hipotesis Kelima menguji apakah Terdapat pengaruh Langusng Motivasi Kerja terhadap kinerja guru di SMA negeri Kabupaten tebo secara P Values positif artinya Terdapat pengaruh. Hasil pengujian menunjukkan bahwa ada pengaruh yang signifikan. Dimana nilai $\mathrm{p}$ Value dibawah 0,05 hipotesis Kelima diterima. Hal tersebut membuktikan bahwa Terdapat pengaruh siginfikan dengan Original Sample sebesar 0,608 (60,8 \%).

Hasil penelitian ini sejalan dengan penelitian yang dilakukan oleh Hadi, tentang pengaruh iklim organisasi dan motivasi mengajar terhadap kinerja guru SMK, SMK, MA Muhamadiyah di kabupaten Kudus, diperoleh kesimpulan bahwa pengaruh variabel iklim organisasi (X1) dan variabel motivasi mengajar (X2) terhadap kinerja profesional guru (Y) sebesar 0,73 atau 73,0\%. Angka ini menunjukan bahwa kinerja guru (Y) secara bersama-sama (simultan) dipengaruhi oleh variabel iklim organisasi (X1) dan variabel motivasi mengajar (X2) sebesar 73,0\%. Dari hasil penelitian maupun dari penelitian terdahulu, maka dapat disampaikan bahwa terdapat pengaruh yang positif dan signifikan antara iklim.

Hipotesis keenam menguji apakah Terdapat pengaruh tidak langsung kepemimpinan terhadap kinerja guu melalui Motivasi Kerja Guru pada SMA Negeri di Kabupaten Tebo secara P Values positif artinya Terdapat pengaruh tidak langsung Kepemimpinan terhadap kinerja Guru melalui Motivasi Kerja Hasil pengujian menunjukkan bahwa ada pengaruh yang signifikan. Dimana nilai $\mathrm{p}$ Value dibawah 0,05 hipotesis Keenam diterima. Hal tersebut membuktikan bahwa Terdapat pengaruh siginfikan dengan Original Sample sebesar 0,207 (20,7\%).

Hipotesis ketujuh menguji apakah Terdapat pengaruh tidak langsung Struktur Organisasi terhadap kinerja guru melalui Motivasi Kerja Guru pada SMA Negeri di Kabupaten Tebo secara P Values positif artinya Terdapat pengaruh tidak langsung Struktur organisasi terhadap kinerja Guru melalui Motivasi Kerja Hasil pengujian menunjukkan bahwa ada pengaruh yang signifikan. Dimana nilai p Value dibawah 0,05 hipotesis Ketujuh diterima. Hal tersebut membuktikan bahwa Terdapat pengaruh siginfikan dengan Original Sample sebesar 0,416 (41,6\%).

Keterbatasan temuan dan makna penelitian terhadap perkembangan keilmuan yaitu secara operasional, fokus penelitian ini dibatasi dalam empat variabel penelitian, yakni kepemimpinan kepala sekolah, struktur organisasi, motivasi kerja guru dan kinerja guru pada SMA Negeri Kabupaten Tebo.

\section{KESIMPULAN}

Berdasarkan analisis hasil penelitian dan pembahasan maka dapat disimpulkan Terdapat pengaruh langsung Kepemimpinan Kepala sekolah SMA Negeri di kabupaten Tebo terhadap kinerja guru. Kepala sekolah sebagai seorang pimpinan di sekolah harus mempunyai jiwa kepemimpinan yang baik, untuk meningkatan kinerja guru terutama dalam perencanaan. Terdapat pengaruh langsung Struktur Organisasi 
932 Pengaruh Kepemimpnan Kepala Sekolah, Struktur Organisasi, Motivasi Kerja Guru Terhadap Kinerja Guru - Tri Puspita Sari, Eddy Haryanto, Mohammad Muspawi

DOI: https://doi.org/10.31004/edukatif.v4i1.2040

terhadap kinerja guru SMA Negeri Kabupaten Tebo, artinya dalam susunan kepengurusan struktur organsasi di sekolah sudah membuat guru nyaman sehingga meningkatkan kinerja guru di kabupaten Tebo. Terdapat pengaruh signifikan Kepemimpinan kepala sekolah terhadap Motivasi kerja guru SMA negeri Kabupaten Tebo. Hal ini mengidenfikasikan bahwa kepemimpinan kepala sekolah mampu menumbuhkan motivasi dalam diri guru dalam menjalankan tugas belaajr mengajarnya. Terdapat pengaruh langsung struktur Organisasi terhadap Motivasi kerja guru di Kabupaten Tebo. Hasil penelitian ini menunjukan bahwa struktur organisasi memberikan dorongan dalam bekerja para guru SMA negeri kabupaten Tebo. Terdapat pengaruh Motivasi kerja terhadap kinerja guru SMA Negeri Kabupaten Tebo. Hal ini diartikan bahwa motivasi meningkatkan kinerja guru. Terdapat pengaruh tidak langsung Kepemimpinan terhadap kinerja guru melalui Motivasi kerja guru SMA negeri Kabupaten Tebo. Dari hal ini dapat diartikan bahwa dengan kepemimpinan baik yang dilakukan kepala sekolah maka motivasi kerja guru akan meningkat hal ini maka akan berdampak terhadap kinerja guru Kabupaten Tebo. Terdapat pengaruh tidak langsung Struktur Organisasi terhadap kinerja guru melalui Motivasi kerja guru SMA Negeri Kabupaten Tebo. Hal ini diartikan bahwa melalui susunan organisasi maka motivasi guru akan meningkat sehingga membuat kinerja guru lebih baik lagi.

\section{UCAPAN TERIMA KASIH}

Terimakasih kepada bapak Eddy Haryanto., M. Sc. Ed., Ph. D selaku Dosen pembimbing I, terima kasih kepada bapak Dr. Mohamad Muspawi., S. Pd. I., M. Pd. I selaku pembimbing II, TIM penguji, Dosen, dan Staf pengelola Pascasarjana Universitas Jambi. Terima kasih kepada Edukatif: Jurnal Ilmu Pendidikan Universitas Pahlawan yang telah bersedia menerbitkan jurnal.

\section{DAFTAR PUSTAKA}

Arikunto, S. (2013). Prosedur Penelitian. Jakarta: Rineka Cipta.

Creswell John. W. (2012). Research Design Pendekatan Kualitatif, Kuantitatif, dan Mixed. Yogyakarta: Pustaka Pelajar.

Farel, G., Ambiyar, Simatupang, W., Giatman, M., \& Syahril. (2021). Analisis Efektivitas Pembelajaran Daring pada SMKdengan Metode Asynchronous dan Synchronous. Edukatif: Jurnal Ilmu Pendidikan, 3, 1185 - 1190. Retrieved from https://edukatif.org/index.php/edukatif/index

FR, G. G.,, \& Nurohmi, A. F. (2017). Persepsi Gaya Kepemimpinan dan Komitmen Organisasi. . JPPP-Jurnal Penelitian dan Pengukuran Psikologi, 6(2), 82-87.

Ghozali, I.,, \& Purwanto. (n.d.). Konstruksi model pengukuran kinerja dan kerangka kerja pengungkapan modal intelektual. Jurnal Akuntansi Multiparadigma, 5(3), 380-392.

Hadiati, E. (2018). Pengaruh Disiplin Kerja terhadap Kinerja Guru Mts se-Kota Bandar Lampung. Al-darah E-jurnal Kependidikan Islam, 8(9) 22-31

Hair, J. F., , Risher, J. J., , Sarstedt, M.,, \& Ringle. (2019). When to use and how to report the results of PLSSEM. European business review.

Iskandar, U. (2013). Kepemimpinan kepala sekolah dalam peningkatan kinerja guru. Jurnal visi ilmu pendidikan, 10(1).

Mastura, D., Gimin, G.,, \& Burhanuddin, D. (2017). Pengaruh Supervisi Kepala Sekolah Terhadap Motivasi Kerja dan Kinerja Guru SMP Di Kecamatan Pesisir Kabupaten Siak. Jurnal Jumped (Jurnal Manajemen Pendidikan), 5(1), 18-27.

Mulyani, \& Jamilus. (2021). Pengembangan Pendidik Sebagai Sumber Daya Manusia di Sekolah Menengah Atas. Edukatif: Jurnal Ilmu Pendidikan, 3(4), 1170 - 1176. https://edukatif.org/index.php/edukatif/index 
933 Pengaruh Kepemimpnan Kepala Sekolah, Struktur Organisasi, Motivasi Kerja Guru Terhadap Kinerja Guru - Tri Puspita Sari, Eddy Haryanto, Mohammad Muspawi

DOI: https://doi.org/10.31004/edukatif.v4i1.2040

Nurlina, I. (2010). Pengaruh Manajemen Kelas dan Etos Kerja Terhadap Efektivitas Proses Belajar Mengajar Guru Sekolah Dasar di Kecamatan Babakan Cikao Kabupaten Purwakarta. Jurnal Admisistrasi Pendidikan Universitas Pendidikan Indonesia, 12. Retrieved from https://ejournal.upi.edu/index.php/JAPSPs/article/view/6380/4338

Nurrohma, R. I., \& Adistana, G. A. (2021). Penerapan Model Pembelajaran Problem Based Learning dengan Media E-Learning Melalui Aplikasi. Edukatif: Jurnal Ilmu PendidikaN, 3(4). https://doi.org/10.31004/edukatif.v3i4.544

Pebrianto, Herpratiwi, \& Fitriawan, H. (2021). Pengembangan Multimedia Pembelajaran Hari Raya Agama Buddhadi Sekolah Minggu Buddhis Bodhisattva. Edukatif: Jurnal Ilmu Pendidikan, 3, 1261 - 1270. Retrieved from https://edukatif.org/index.php/edukatif/index

Prabu, M. A. (2005). Perilaku dan Budaya Organisasi. Bandung: PT. RafikaAditama.

Qolb, S. K., \& Hamami, T. (2021, Universitas Pahlawan tuanku Tambusai Riau). Impelementasi Asas-asas Pengembangan Kurikulum terhadap Pengembangan KurikulumPendidikan Agama Islam. Edukatif: Jurnal Ilmu Pendidikan, 3(4), 1120 - 1132. doi:https://edukatif.org/index.php/edukatif/index

Rizal, A. S. (2019). Pengaruh Motivasi Kerja dan Kedisiplinan terhadap Kinerja Guru SMP. Ulul Albab, 3, $15-22$.

Sah, K., \& Mulyasa, E. (2018). Pengaruh Gaya Kepemimpinan Situasional dan Motivasi Kerja Terhadap Kinerja Pegawai. Fokus Manajemen Pendidikan, 1(1), 37-44.

Siska, J. (2017). Pengaruh Disiplin dan Motivasi Kerja terhadap Kinerja Guru pada SMAN 1 Canduang Kabupaten Agam. J.U.S.I.E, 1(2), 45-54.

Sopaheluakan. (2020). Hubungan antara Kepemimpinan Kepala Sekolah dan Budaya Kerja dan Kinerja Guru SMA Negeri 1 Seram Barat Kabupaten Seram. e-Jurnal UKI, 9(2), 23-31.

Umam (2010). Perilaku Organisasi. Bandung: CV Pustaka Setia.

Wahid, I. A. (2016). Pengaruh Motivasi, Etos Kerja dan Disiplin Kerja Terhadap Kinerja Pegawai Negeri Sipil (PNS) pada Dinas Kehutanan dan Perkebunan Daerah Kabupaten Morowali. Jurnal Katalogis, Volume 4 Nomor 8, Agustus 2016 hlm 156-163, 4. Retrieved from https://media.neliti.com > media > publications 